\title{
SHP2 inhibition ameliorates disease in lupus-prone mice
}

$\begin{array}{ll}\text {... SHP2 } & \begin{array}{l}\text { Variation in the gene region } \\ \text { encoding the tyrosine phosphatase } \\ \text { inhibition }\end{array} \\ \text { SHP2 is associated with systemic } \\ \text { lupus erythematosus (SLE), and a } \\ \text { proportion of patients who carry } \\ \text { gain-of-function SHP2 mutations } \\ \text { develop SLE. A new study provides } \\ \text { MRL/Ipr mice .... }\end{array} \quad \begin{aligned} & \text { further evidence implicating SHP2 } \\ & \text { in the pathogenesis of SLE and shows } \\ & \text { that inhibition of SHP2 ameliorates } \\ & \text { disease in lupus-prone MRL/lpr mice. } \\ & \text { SHP2 activity was significantly } \\ & \text { increased in splenocytes isolated } \\ & \text { from female MRL/lpr mice and in } \\ & \text { peripheral blood mononuclear cells } \\ & \text { from women with SLE compared } \\ & \text { with cells from control mice and } \\ & \text { healthy women, respectively. } \\ & \text { In MRL/lpr } \text { splenocytes, increased } \\ & \text { SHP2 activity was associated with } \\ & \text { aberrant ERK-MAPK signalling } \\ & \text { that could be corrected by treatment } \\ & \text { with the potent SHP2-selective } \\ & \text { inhibitor 11-a1. }\end{aligned}$

To determine the relevance of increased SHP2 activity to disease, the authors treated MRL/lpr mice with either vehicle or 11-a1 for 6 weeks from the age of disease onset (12 weeks). "We were amazed by the profound amelioration of ... the disorder in response to the SHP2 inhibitor," says Maria Kontaridis, lead author of the study. "The skin lesions were ameliorated, the spleen was reduced in size and the kidney looked normal." In addition, SHP2 inhibition markedly improved the survival of MRL/lpr mice: whereas no vehicle-treated mice survived at week $26,>80 \%$ of 11 -a1-treated mice remained alive at this time point.

The authors went on to investigate the mechanisms underlying the observed disease amelioration. SHP2 inhibition was found to significantly reduce the number of circulating double-negative (DN) T cells, and

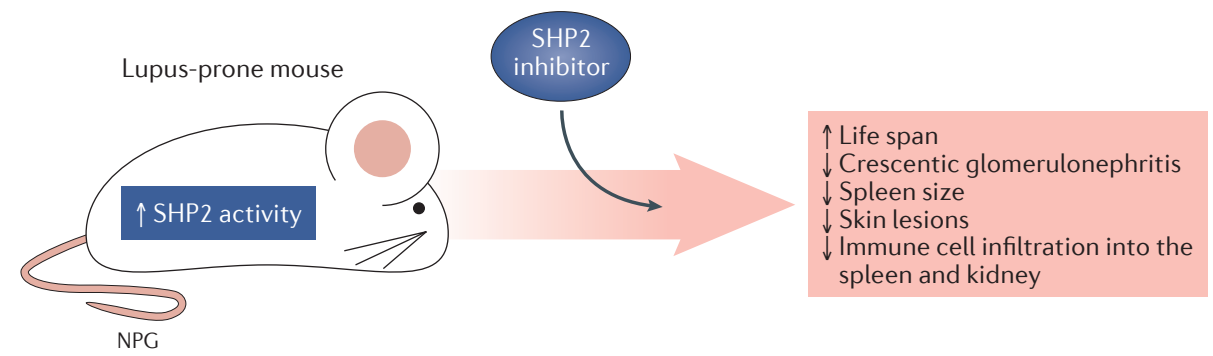

also decrease $\mathrm{T}$ cell proliferation and immune cell infiltration into the spleen and kidney. Further experiments revealed that $11-\mathrm{a} 1$ treatment significantly reduced circulating levels of IFN $\gamma$ and the IL-17A-IL-17F heterodimer in $\mathrm{MRL} / \mathrm{lp} r$ mice, which was found to reflect decreased cytokine production by lymph node DN T cells. Notably, the role of SHP2 in $\mathrm{T}$ cell proliferation and cytokine production also translated into the human setting: compared with $\mathrm{T}$ cells from patients with active SLE that were cultured in control conditions, cells treated with 11-a1 showed significantly reduced proliferation and production of IFN $\gamma$ and IL-17A-IL-17F.

In summary, this study provides functional data supporting a role for SHP2 in the pathogenesis of SLE. "It is our hope that blocking SHP2 will someday soon be a novel and effective therapy for treatment of patients ... with SLE," explains Kontaridis.

Lydia Shipman

ORIGINAL ARTICLE Wang, J. et al. Inhibition of SHP2 ameliorates the pathogenesis of systemic lupus erythematosus. J. Clin. Invest. http://dx.doi. org/10.1172/JCl87037 (2016) 